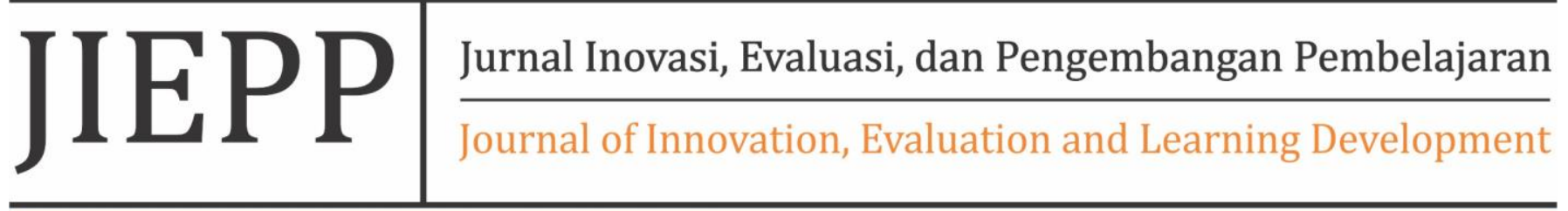

\section{Kajian Konseptual Model Pembelajaran Word Square untuk Meningkatkan Hasil Belajar Siswa}

\author{
Cintia Rinjani' ${ }^{1}$, Fauza Izza Wahdini' ${ }^{2}$, Elvira Mulia ${ }^{3}$, Supratman Zakir ${ }^{4}$, Siska Amelia $^{5}$ \\ 1.2,3 Mahasiswa Program studi S2 Pendidikan Agama Islam, IAIN Bukittinggi \\ ${ }^{4}$ Dosen Program studi S2 Pendidikan Agama Islam, IAIN Bukittinggi \\ ${ }^{5}$ Dosen Program studi Pendidikan Agama Islam, IAIN Sultan Amai Gorontalo \\ E-mail:cintiarinjani07@gmail.com, fauzaizza29@gmail.com, supratman@iainbukittinggi.ac.id, \\ elviramulia03@gmail.com, siskaameliarizky@gmail.com
}

Article History: Received: 2021-10-12 || Revised: 2021-11-27 || Published: 2021-12-30

Sejarah Artikel : Diterima: 2021-10-12 || Direvisi: 2021-11-27 || Dipublikasi: 2021-12-30

\begin{abstract}
In this article describes a study of journal content from several research results related to the wors square learning model. The results of research journals were analyzed based on the results of searching online journal databases. This article examines more than 10 national journals that focus on the word square learning model. The results of the concept study from several journals that the word square model is the development of the lecture learning model. Students are expected to always be active and be able to find a way of learning that suits them. The teacher only works as a mediator, facilitator, and friend who creates a conducive situation for learning to occur in students. Word Square will strengthen the conventional learning model or lecture. In addition, the results of research in journals can be said that the average word square research results also have an influence on learning outcomes.
\end{abstract}

Keywords: Model, Learning, Word Square, Learning result

\begin{abstract}
Abstrak
Pada artikel ini memaparkan kajian isi jurnal dari beberapa hasil penelitian yang difokuskan pada model pembelajaran wors square. Hasil jurnal penelitian yang dianalisis berdasarkan hasil penelurusuran database jurnal online. Pada artikel ini jurnal yang dikaji berjumlah kurang lebih 10 jurnal nasional yang berfokus pada model pembelajaran word square. Hasil dari kajian konsep dari beberapa jurnal bahwa model word square merupakan pengembangan dari model pembelajaran ceramah. Peserta didik diharapkan bisa selalu aktif dan dapat menemukan cara belajar yang sesuai dengan dirinya. Guru hanya berfungsi sebagai mediator, fasilitor dan teman yang membuat situasi yang kondusif untuk terjadinya konstruksi pengetahuan pada diri peserta didik. Word Square ini akan memperkuat metode pembelajaran ceramah. Selain itu hasil kajian pada jurnal dapat disimpulkan bahwa rata-rata hasil penelitian word square juga memberikan pengaruh terhadap hasil belajar.
\end{abstract}

Kata kunci: Model, Pembelajaran, Word Square, Hasil belajar

\section{PENDAHULUAN}

Pendidikan merupakan suatu hal yang sangat penting yang tidak dapat dipisahkan dari kehidupan manusia. Sifatnya mutlak dalam kehidupan seseorang, keluarga, maupun bangsa dan negara. Sebab maju mundurnya suatu bangsa ditentukan oleh pendidikan bangsa itu sendiri. Sebagaimana yang terdapat dalam Undang-Undang Nomor 20 Tahun 2003 Bab II Pasal 3 tentang Sistem Pendidikan Nasional menerangkan bahwa : "Pendidikan nasional berfungsi mengembangkan kemampuan dan membentuk watak serta peradaban bangsa yang bermartabat dalam rangka mencerdaskan kehidupan bangsa, bertujuan untuk berkembangnya potensi peserta didik agar menjadi manusia yang beriman dan bertaqwa kepada Tuhan Yang Maha Esa, berakhlak mulia, berilmu, cakap, kreatif, mandiri dan menjadi warga Negara yang demokratis dan bertanggung jawab".(Kurino et al., 2019), kegiatan pendidikan dan pembelajaran pada hakekatnya adalah proses interaktif Keterkaitan antara guru dan siswa dalam satuan pembelajaran. Guru merupakan Salah satu komponen proses pendidikan dan pembelajaran sehingga mempunyai peran yang sangat penting. Guru tidak hanya 
sekedar penyampai materi, tetapi lebih dari itu, guru merupakan pusat pembelajaran.

Pendidik mempunyai peranan yang sangat berpengaruh dalam pembelajaran, tidak hanya sekedar menyampaikan pengetahuan saja, tetapi pendidik juga harus menjadikan pembelajaran berlangsung lebih aktif. Model atau metode yang digunakan oleh pendidik akan berpengaruh pada aktivitas siswa, jika pendidik menggunakan model yang melibatkan peserta didik supaya lebih rajin, namun sebaliknya apabila pendidik hanya menjelaskan saja tentu akan membuat peserta didik merasa bosan dan jenuh saat belajar. pemilihan dan penggunaan model pembelajaran yang sesuai, maka akan mempengaruhi minat belajar peserta didik sehingga pelajaran bisa lebih aktif dan hasil belajar bisa meningkat.(Fauhah, 2021).

Fenomena yang terjadi sampai sekarang banyak guru yang pada saat proses pembelajaran masih menggunakan metode ceramah saja, hal tersebut dapat membuat siswa menjadi jenuh dan bosan, hasil observasi yang dilakukan oleh Ni Wayan Lasmini, model pembelajaran yang diterapkan oleh guru saat proses belajar mengajar masih menggunakan model konvensional yang mana masih berpusat kepada guru (teacher center). Siswa hanya duduk dan menerima materi yang disampaikan oleh guru saja.(Lasmini, n.d.) Sedangkan hasil observasi Suwardi aktivitas siswa pada saat proses pembelajaran lebih banyak diam. Siswa hanya sekedar mendengarkan dan menulis dari apa yang dijelaskan oleh guru. Guru dalam kegiatan pembelajaran tidak menggunakan berbagai macam model pembelajaran.

Salah satu model pembelajaran yang dapat digunakan dalam mengatasi fenomena di atas ialah Word Square, dalam word square pencapaian keberhasilan siswa karena pada model ini setiap siswa mesti sama-sama harus menguasi materi yang dipelajari. Hasil Penelitian Khoiriyah Suryani (2018) yang berjudul "Pengaruh Model Pembelajaran Word Square Terhadap Aktivitas Dan Hasil Belajar Siswa Kelas V Mata Pelajaran Bahasa Inggris Di MIN 8 Bandar Lampung", hasilnya menunjukan bahwa dengan menggunakan model word square siswa bisa mengembangkan keterampilan dan pengetahuannya sesuai dengan potensi yang ia miliki sehingga siswa aktif dalam proses pembelajaran dan pembelajaran menjadi menyenangkan.

\section{METODE PENELITIAN}

Pada artikel ini membahas tentang Word Square yang digunakan dalam pembelajaran. Berdasarkan kajian jurnal penelitian dari pelbagai sumber jurnal online. Artikel jurnal yang menjadi kajian pada artikell ini berjumlah kurang lebih 10 jurnal penelitian. Adapun judul penelitian sebagai berikut:

Tabel 1. Rujukan Penelitian terdahulu

\begin{tabular}{|c|c|c|}
\hline No & Judul & Penulis \\
\hline 1 & $\begin{array}{l}\text { Penerapan Model Pembelajaran Word Square Untuk } \\
\text { Meningkatkan Hasil Belajar Ipa Siswa Kelas V } \\
\text { Semester Genap }\end{array}$ & $\begin{array}{l}\text { AA Ngurah Agung Swapranata, Pt. Nanci } \\
\text { Riastini, I Gst. Ngurah Japa. } \\
\text { urusan PGSD, FIP Universitas Pendidikan } \\
\text { Ganesha Singaraja, Indonesia. } \\
\text { e-mail: agung nata93@yahoo.co.id }\end{array}$ \\
\hline 2 & $\begin{array}{l}\text { Penerapan Model Pembelajaran Word Square Untuk } \\
\text { Meningkatkan Prestasi Belajar Siswa Kelas V SDN } \\
\text { Pengawu }\end{array}$ & $\begin{array}{l}\text { Sayid Abdullah } \\
\text { SD Negeri Pengawu }\end{array}$ \\
\hline 3 & $\begin{array}{l}\text { Penerapan Model Pembelajaran Word Square Untuk } \\
\text { Meningkatkan Hasil Belajar Siswa Kelas X Pada } \\
\text { Mata Pelajaran Akuntansi Perusahaan Jasa Di Smk } \\
\text { Pasundan } 1 \text { Kota Serang }\end{array}$ & $\begin{array}{l}\text { Reni Febriani, Selvi Lucyana. } \\
\text { Universitas Banten Jaya Serang, Indonesia. } \\
\text { Email : } \underline{\text { renote28@gmail.com }}\end{array}$ \\
\hline 4 & $\begin{array}{l}\text { Penerapan Model Pembelajaran Word Square Untuk } \\
\text { Menigkatkan Hasil Belajar Ips Siswa Kelas } 3 \text { Sdn } 2 \\
\text { Slempit Kedamean Gresik }\end{array}$ & $\begin{array}{l}\text { Brili Herwandannu, Suprayitno } \\
\text { PGSD FIP Universitas Negeri Surabaya. } \\
\text { Herwandannu07@gmail.com }\end{array}$ \\
\hline 5 & $\begin{array}{l}\text { Model Word Square Untuk Meningkatkan Hasil } \\
\text { Belajar Siswa Sekolah Dasar }\end{array}$ & $\begin{array}{l}\text { Yeni Dwi Kurino, Yuyun Dwi Haryati, } \\
\text { Uswatun Hasanah. } \\
\text { Program Studi PGSD Universitas } \\
\text { Majalengka. } \\
\text { Jalan K.H Abdul Halim No.103 Majalengka, } \\
45417 \text { yenidwi kurino@yahoo.com }\end{array}$ \\
\hline
\end{tabular}




\begin{tabular}{|c|c|c|}
\hline 6 & $\begin{array}{l}\text { Efektivitas Model Pembelajaran Word Square } \\
\text { Terhadap Hasil Belajar Siswa Pada Mata Pelajaran } \\
\text { Pai Dan Budi Pekerti Kelas Ix Di Smp Negeri } 7 \\
\text { Depok }\end{array}$ & $\begin{array}{l}\text { Silmi Salsabila, Abas Asyafah, dan Saepul } \\
\text { Anwar }\end{array}$ \\
\hline 7 & $\begin{array}{l}\text { Penerapan Model Pembelajaran Word Square Pada } \\
\text { Materi Globalisasi Untuk Meningkatkan Hasil } \\
\text { Belajar Siswa Kelas Iv Semester Ii Sdn Sidorejo I } \\
\text { Kabupaten Tuban Ta 2016-2017 }\end{array}$ & $\begin{array}{l}\text { Iis Daniati Fatimah } \\
\text { UNIROW Tuban } \\
\text { e-mail: iisdaniatifatimah2@gmail.com }\end{array}$ \\
\hline 8 & $\begin{array}{l}\text { Penggunaan model pembelajaran word square } \\
\text { untuk meningkatkan hasil belajar siswa pada } \\
\text { pelajaran pendidikan kewarganegaraan di kelas v } \\
\text { sd negeri } 054938 \text { kab. Langkat }\end{array}$ & $\begin{array}{l}\text { Numayani } \\
\text { nurmayani@gmail.com }\end{array}$ \\
\hline 9 & $\begin{array}{l}\text { Penerapan Model Pembelajaran Word Square untuk } \\
\text { Meningkatkan Aktivitas dan Hasil Belajar Siswa } \\
\text { Kelas V Mata Pelajaran PKn Pokok Bahasan } \\
\text { Keputusan Bersama di SDN Umbulrejo 01 Jember }\end{array}$ & $\begin{array}{l}\text { Yesi Ratnasari, Yayuk Mardiati, Chumi } \\
\text { Zahroul Fitriyah } \\
\text { Jurusan Ilmu Pendidikan, Fakultas } \\
\text { Keguruan dan Ilmu Pendidikan, Universitas } \\
\text { Jember (UNEJ) } \\
\text { Jln. Kalimantan 37, Jember 68121 E-mail: } \\
\text { chumizahroul@yahoo.com }\end{array}$ \\
\hline 10 & $\begin{array}{l}\text { Penerapan Model Pembelajaran Kooperatif Tipe } \\
\text { Word Square Dalam Meningkatkan Hasil Belajar Ips } \\
\text { Siswa Sd }\end{array}$ & $\begin{array}{l}\text { Sitti Jauhar, Andi Desri Indarwati } \\
\text { DOsen Prodi PGSD FIP UNM } \\
\text { Prodi PGSD FIP UNM } \\
\text { Email: st.jauhar@gmail.com }\end{array}$ \\
\hline
\end{tabular}

Artikel-artikel di atas sebagai referensi bahan untuk mengkaji teori Word Square, sekaligus mengkaji metodologi, teknik pengumpulan data, instrument penelitian serta analisis data yang digunakan, yang nantinya sebagai referensi untuk penelitian selanjutnya. Dari 10 artikel yang dikaji, menunjukan terdapat jurnal penelitian berbentuk kuantitatif, dan kualitatif, berikut penjelasan isi dari beberapa jurnal sebagai referensi dalam rancangan thesis. Pada tulisan artikel ini hanya 5 saja yang ditulis:

1) Jurnal yang berjudul "Penerapan Model Pembelajaran Word Square Untuk Meningkatkan Hasil Belajar Ipa Siswa Kelas V Semester Genap", membahas tentang penerapan model word square yang diterapkan pada sampel 28 siswa yang terdiri dari 13 laki-laki dan 15 perempuan. Pengumpulan data menggunakan metode tes, dengan instrument soal essay. Hasil penelitian menunjukan terjadi peningkatan hasil belajar siswa dari siklus I sampai siklus II.(Ngurah et al., 2016).

2) Jurnal yang berjudul "Penerapan Model Pembelajaran Word Square Untuk Meningkatkan Prestasi Belajar Siswa Kelas V SDN Pengawu", Tujuan penelitian ini adalah untuk meningkatkan prestasi belajar PKn konsep Materi Pengertian Perundang-Undangan¥ dengan menggunakan model pembelajaran Word Square. Penelitian tindakan kelas ini dilaksanakan dalam 2 siklus. Subjek penelitian seluruh siswa Kelas V SDN Pengawu yang berjumlah 23 siswa. Metode pengumpulan data melalui observasi, dokumentasi dan tes. Analisis data dilakukan dengan 3 tahapan meliputi: reduksi data, penyajian data dan penarikan kesimpulan. Hasil penelitian menunjukan bahwa prestasi belajar siswa dengan menggunakan model Pembelajaran Word Square mengalami peningkatan setelah model ini diaplikasikan.(Abdullah, n.d.).

3) Jurnal yang berjudul "Penerapan Model Pembelajaran Word Square Untuk Meningkatkan Hasil Belajar Siswa Kelas X Pada Mata Pelajaran Akuntansi Perusahaan Jasa Di Smk Pasundan 1 Kota Serang", Penelitian ini menggunakan desain penelitian tindakan kelas. Teknik Pengumpulan Data yang digunakan dalam penelitian ini adalah tes, observasi, wawancara, dan dokumentasi. Sedangkan pengumpulan data dilakukan dengan lembar observasi, soal tes dan pedoman dokumentasi. Hasil penelitian penerapan mdel pembelajaran word square dapat meningkatkan hasil belajar siswa. Pada siklus 1 ketuntasan belajar siswa dalam kelas adalah $72,73 \%$ atau sebanyak 31 orang siswa, sedangkan ketuntasan belajar siswa dalam kelas pada siklus 2 adalah 100\% atau 44 orang siswa.(Reni Febriani, 2018).

4) Jurnal yang berjudul "Penerapan Model Pembelajaran Word Square Untuk Menigkatkan Hasil Belajar Ips Siswa Kelas 3 Sdn 2 Slempit Kedamean Gresik", Jenis penelitian ini adalah 
penelitian tindakan kelas, penelitian dilakukan sebanyak 2 siklus dengan lokasi penelitian di SDN 2 Slempit Kedamean Gresik. Penelitian ini bertujuan untuk mendeskripsikan peningkatan aktivitas guru, aktivitas siswa, dan hasil belajar pada mata pelajaran IPS dengan menerapkan model pembelajaran Word Square. Subjek penelitiannya adalah guru dan siswa kelas 3. Hasil yang didapatkan dari penelitian yang telah dilakukan pada hasil belajar siklus I adalah $69 \%$, pada siklus II 90\%. Data aktivitas guru pada siklus I 76,25\%, pada siklus II 90\%. Dan aktivitas siswa pada siklus I adalah 75\%, pada siklus II 91,25\%. Dari data yang diperoleh dapat diambil kesimpulan bahwa model pembelajaran Word Square dapat meningkatkan hasil belajar siswa.(Herwandannu, 2018).

5) Jurnal yang berjudul "Model Word Square Untuk Meningkatkan Hasil Belajar Siswa Sekolah Dasar", Penelitian ini dilaksanakan dalam dua siklus. subjek penelitian adalah siswa kelas V sebanyak 34 orang. Pelaksanaan penelitian terdiri dari dua siklus dan setiap siklus terdiri dari dua tindakan. Teknik pengumpulan data dilakukan dengan menggunakan lembar observasi, catatan lapangan, lembar wawancara, lembar evaluasi dan kamera. Dari Hasil belajar yang diperoleh setiap siklus mengalami peningkatan. Rata-rata hasil belajar mulai dari data awal 49,20\%, 66,02\%, 75\%, 77,05\% dan hingga mencapai 78,23\%. Dengan demikian peneliti menyimpulkan bahwa model word square dapat meningkatkan Hasil Belajar siswa kelas V Sekolah Dasar.(Kurino et al., 2019).

\section{HASIL DAN PEMBAHASAN}

A. Pengertian Model Pembelajaran Word Square

Supaya kegiatan belajar mengajar bisa erjadi dengan baik maka harus memperhatikan banyak fakotr, salah satunya ialah dengan memperhatikan model pembelajaran. Proses pembelajaran berlangsung dengan efektif dan efesien, ialah dengan mengembangangkan metode pembelajaraan, pengelolaan pembelajaran dan hal-hal lain yang bisa menunjang proses pembelajaran.(Sadirman, 2005) Salah satu model pembelajaran yang bisa digunakan dalam kegiatan pembelajaran oleh pendidik ialah model pembelajaran inovatif tipe word square, kata word square berasal dari bahasa Inggris, word berarti kata, dan square berarti sesuatu yang berbentuk persegi atau kotak(Shadily, 1976). Jadi word square bisa diartikan dengan kata-kata yang dimasukkan ke dalam kotak atau persegi. Model pembelajaran word square ialah pengembangan dari metode ceramah yang mana memfokuskan pada keaktifan siswa dalam kegiatan pembelajaran.(Kurniasih, 2016), Model pembelajaran word square menurut para ahli:

1) Menurut Mudjion, word square merupakan sejumlah kata yang disusun sehingga kata-kata tersebut dapat dibaca ke depan dan ke belakang.(Fatimah, 2019)

2) Menurut Kurniasih dan Sani, model pembelajaran word square merupakan sebuah model pembelajaran yang berorientasi kepada ketelitian siswa. Model pembelajaran word square ini dapat melatih ketelitian dan kemampuan siswa saat mencocokan huruf yang telah disediakan di kotak jawaban menjadi sebuah kata yang benar. Pada kotak jawaban tersedia banyak huruf yang disamarkan dengan tujuan sebagai pengecoh(Herwandannu, 2018).

3) Menurut Alamsyah Said dan Budimanjaya dalam buku Strategi Mengajar, word square adalah permainan menemukan kata-kata tertentu dalam kolom yang tersusun secara acak.(Ni Pd. Mirah Kurniasari. dkk, n.d.)

4) Menurut teori Urdang, word square is a set of word such that when arranged one beneath another in the form of a square the read a like horizontally, artinya word square adalah sejumlah kata yang disusun satu dibawah yang lain dalam bentuk bujur sangkar dan dibaca secara mendatar dan menurun.(Ni Pd. Mirah Kurniasari. dkk, n.d.)

Model pembelajaran word squre ialah model pembelajaran yang bisa dipakai guru untuk mencapai tujuan pembelajaran. Dalam prakteknya model word square ini ialah kegiatan belajar mengajar dengan cara guru memberikan lembar kegiatan atau lembar kerja sebagai alat untuk mlihat tingkat pemahaman siswa mengani materi pelajaran yang telah diberikan dan diajarkan. Model pembelajaran word square ini merupakan model pembelajaran yang memadukan kemampuan dalam menjawab pertanyaan dengan kejelian dalam mencocokan jawaban pada kotak-kotak jawaban yang telah disediakan. Kotak-kotak tersebut akan diisi oleh siswa dengan cara mengarsir huruf-huruf yang ada yang merupakan jawaban dari pertanyaan yang diberikan oleh guru. Model pembelajaran ini mempunyai sedikit kemiripan dengan teka-teki silang, namun perbedaan dari 
keduanya adalah model pembelajaran word square ini sudah memiliki jawaban, tetapi disamarkan dan diberi kota tambahan dengan sembarang huruf atau angka yang bertujuan sebagai pengecoh.(Numayani, 2018).

Keistimewaan dari model pembelajaran ini ialah dapat digunakan pada semua mata pelajaran. Tergantung bagaimana guru memprogram kegiatan pembelajaran dengan pertanyaan yang bisa menarik siswa agar berfikir secara efektif. Dalam model pembelajaran word square tersedia banyak sekali huruf-huruf yang tidak diperlukan, namun haruf tersebut dipakai sebagai pengecoh tidak untuk mempersulit siswa. Model pembelajaran word square ini juga dapat dibilang model pembelajaran yang melalui permainan artinya belajar sambil bermain, namun lebih menekankan kepada belajarnya. Belajar sambil bermain juga akan berdampak positif terhadap siswa disebabkan akan terjadikan perubahan sikap, pengalaman belajar, dan tingkah laku siswa.(Herwandannu, 2018).

Dengan menerapkan model pembelajaran word square, diharapkan dapat meningkatkan kemampuan siswa dan juga dapat membantu mencapai tujuan pembelajaran yang dapat dilihat dari hasil belajar. untuk mengukur seberapa jauh seorang siswa dalam menguasai bahan yang sudah diajarkan biasanya digunakan hasil belajar. Untuk mengaktualisasikan hasil belajar diperlukan serangkaian pengukuran menggunakan alat evaluasi yang baik dan memnuhi syarat.(Silmi Salsabila, Abas Asyafah, 2018), Alasan digunakannya model pembelajaran word square, dikarenakan model ini melibatkan peserta didik menjadi aktif secara langsung di dalam kelas dan juga bisa melatih kedisipilinan siswa. dalam prakteknya, akan terjadi interaksi komunikatif antara pendidik dengan peserta didik disebabkan peserta didik terlibat aktif dalam pembelajaran.(Ratnasari et al., 2014)

B. Karakteristik Model Pembelajaran Word Square

Beberapa karakteristik metode pembelajaran word square diantaranya sebagai berikut:

1) Model pembelajaran ini mampu sebagai pendorong dan penguat siswa terhadap materi yang disampaikan.

2) Melatih ketelitian dan ketepatan dalam menjawab dan mencari jawaban dalam lembar kerja.

3) Mendorong siswa untuk berfikir efektif terhadap jawaban mana yang paling tepat.

4) Word Square merupakan salah satu alat bantu/media pembelajaran berupa kotak-kotak kata yang berisi kumpulan huruf.

5) Mengajak siswa mengamati suatu objek yang dipadukan dengan lembar kegiatan word square.(Suryani, 2018)

C. Kelebihan dan Kekurangan Model Pembelajaran Word Square

Setiap model, strategi, metode maupun teknik pembelajaran memiliki kelemahan dan kelebihan. Dibawah ini merupakan kelebihan dari model pembelajaran word square, diantaranya:

1) Proses pembelajaran dengan model pembelajaran word square mendorong pemahaman siswa terhadap materi pembelajaran.

2) Siswa akan terlatih untuk disiplin.

3) Sebagai latihan untuk bersikap teliti dan kritis.

4) Merangsang siswa untuk berfikir efektif.

5) Dapat mempermudah guru dalam menguraikan materi ajar, sebab guru dapat mengarahkan siswa kepada pokok-pokok yang telah dipersiapkan sebelumnya.

6) Dapat meningkatkan aktivitas belajar anak, sebab ia akan terus mengarsir huruf sesuai dengan jawabannya.

7) Menghindari rasa bosan anak dalam belajar, sebab adanya aktivitas yang tidak membuat anak jenuh dan bosan mengikuti pelajaran.(Istarani, 2014)

Model pembelajaran ini dapat menjadi penguat dan pendorong bagi siswa terhadap materi yang diberikan. Dapat melatih ketepatan dan ketelitian siswa dalam menjawab dan mencari jawaban dalam lembar kerja. Dan yang paling ditekankan pada model pembelajaran ini ialah untuk berpikir efektif, jawaban apa yang paling sesuai, sedangkan kelemahan dari model pembelajaran word square adalah:

1) Dengan materi yang telah dipersiapkan, akhirnya dapat mengumpulkan kreativitas siswa. 
2) Siswa tinggal menerima bahan mentah.

3) Siswa tidak dapat mengembangkan materi yang ada dengan kemampuan atau potensi yang dimilikinya.

4) Membuat kotak yang bervariasi membutuhkan kreativitas dari seorang guru.

5) Sering kali dijumpai antara kotak yang tersedia tidak sesuai dengan pertanyaan yang ada.

6) Membuat pertanyaan yang memerlukan jawaban yang pasti membutuhkan kemampuan tinggi dari seorang guru.(Istarani, 2014)

Pada model pembelajaran ini murid tidak bisa mengembangkan kreativitas yang dimilikinya, karena lebih banyak berpusat pada guru. Disebabkan siswa hanya menerima apa yang diberikan oleh guru, untuk jawabn pada lembar kerja juga tidak bersifat analisis, menjadikan siswa tidak bisa mencari materi lebih dalam dengan menggunakan pembelajaran word square ini.

D. Langkah-langkah Model Pembelajaran Word Square

Sebelum menerapkan model pembelajaraan word square saat proses pembelajaran, hendaknya guru menjalankan beberapa prosedur model pembelajaran word square. Prosedur pembelajaran word square diantaranya:

1) Menentukan topic sesuai konsep atau sub konsep.

2) Menuliskan kata-kata kunci sesuai dengan tujuan yang akan dicapai.

3) Menuliskan kembali kata-kata kunci dimulai dengan kata-kata terpanjang.

4) Membuat kotak word square.

5) Mengisikan kata-kata kunci pada kotak word square.

6) Menambahkan huruf pengisian ke kotak kosong secara acak.(Silmi Salsabila, Abas Asyafah, 2018).

Dalam menerapkan model pembelajaran word square ada beberapa langkah yang mesti dilakukan. Langkah-langkah model pembelajaran word square adalah sebagai berikut:

1) Guru memberikan materi sesuai dengan topic pembahasan yang dikaji dengan metode ceramah.

2) Guru kemudian membagikan lembaran kegiatan berupa susunan huruf yang mengandung kata yang terdapat dalam materi ajar.

3) Siswa kemudian memilih kata yang tepat dengan soal yang telah diberikan, setelah itu siswa mengarsir huruf dalam kotak sesuai dengan jawaban.

4) Setelah selesai, guru memberikan nilai sesuai dengan jumlah jawaban yang benar dari siswa.(Reni Febriani, 2018).

Menurut Uno dan Mohamad mengemukakan langkah-langkah pembelajaran word square sebagai berikut:

1) Sampaikan materi sesuai kompetensi.

2) Bagikan lembar jawaban.

3) Siswa disuruh menjawab soal kemudian mengarsir huruf dalam kotak sesuai jawaban.

4) Berikan poin setiap jawaban dalam kotak.(Suryani, 2018)

Selanjutnya, Ridwan Abdullah Sani merumuskan bahwa langkah-langkah penerapan model pembelajaran word square dalam kegiatan pembelajaran sebagai berikut:

1) Guru menyampaikan materi ajar sesuai dengan topic bahasan.

2) Guru membagikan lembar kegiatan berupa susunan huruf yang mengandung kata yang terdapat dalam materi yang diajarkan.

3) Siswa mencari kata yang tepat dengan pertanyaan yang diberikan, kemudian mengarsir hruuf kalam kotak yang telah disediakan sesuai jawaban.

Dari uraian langkah-langkah pelaksanaan pembelajaran word square di atas dapat disimpulkan bahwa pelaksanaan word square harus disesuaikan dengan materi pembelajaran. Dari segi materi pun pelaksanaannya harus sesuai. Dalam penelitian ini, peneliti menggunakan langkah-langkah sesuai dengan langkah-langkah pelaksanaan di atas, dan dikombinasikan dengan media pembelajaran yang ada serta dikaitkan dengan materi pembelajaran. (Suryani, 2018). 


\section{SIMPULAN DAN SARAN}

\section{A. Simpulan}

Model pembelajaran word square dibuat berdasarkan pada pola piki bahwa ingatan dapat dibangkitkan dengan memberikan sedikit rangsangan dan informasi seperti lambing-lambang tersebut bisa dirangkai menjadi satu hubungan yang memiliki makna. Bentuk word square juga bisa melatih peserta didik dalam berpikir kreatif. berpikir kreatif menurut Sarlito adalah berpikir menemukan hubungan-hubungan baru antara berbagai hal, kelebihan model pembelajaran word square yaitu: 1) Proses pembelajaran dengan model pembelajaran word square mendorong pemahaman siswa terhadap materi pembelajaran, 2) Siswa akan terlatih untuk disiplin, 3) Sebagai latihan untuk bersikap teliti dan kritis, 4) Dapat mempermudah guru dalam menguraikan materi ajar, sebab guru dapat mengarahkan siswa kepada pokok-pokok yang telah dipersiapkan sebelumnya, 5) Menghindari rasa bosan anak dalam belajar, sebab adanya aktivitas yang tidak membuat anak jenuh dan bosan mengikuti pelajaran, 6) Merangsang siswa untuk berfikir efektif, 7) Dapat meningkatkan aktivitas belajar anak, sebab ia akan terus mengarsir huruf sesuai dengan jawabannya.

\section{B. Saran}

Model pembelajaran word square dalam membuat pertanyaan yang memerlukan jawaban yang pasti membutuhkan kemampuan tinggi dari seorang guru. Upaya untuk meningkatkan dan melatih keaktifan peserta didik membutuhkan rangsangan dari guru. Untuk itu disarankan kepada pendidik untuk mampu memahami model pembelajaran word square agar mampu melatih keaktifan siswa dan membuat suasana pembelajaran menjadi lebih menyenangkan.

\section{DAFTAR RUJUKAN}

Abdullah, S. (n.d.). Penerapan Model Pembelajaran Word Square Untuk Meningkatkan Prestasi Belajar Siswa Kelas V SDN Pengawu. 4(11), 272-279.

Fatimah, I. D. (2019). PENERAPAN MODEL PEMBELAJARAN WORD SQUARE PADA MATERI GLOBALISASI UNTUK MENINGKATKAN HASIL BELAJAR SISWA KELAS IV SEMESTER II SDN SIDOREJO I KABUPATEN TUBAN TA 2016-2017. ELSE (Elementary School Education Journal), 3(1), 18-27.

Fauhah, H. (2021). Analisis Model Pembelajaran Make A Match terhadap Hasil Belajar Siswa Analisis Model Pembelajaran Make A Match terhadap Hasil Belajar .... Jurnal Pendidikan Administrasi Perkantoran (JPAP), 9(2), 321-334.

Herwandannu, B. (2018). PENERAPAN MODEL PEMBELAJARAN WORD SQUARE UNTUK MENIGKATKAN HASIL BELAJAR IPS SISWA KELAS 3 SDN 2 SLEMPIT KEDAMEAN GRESIK. JPGSD, 06(12), 2201-2210.

Istarani. (2014). 58 Model Pembelajaran Inovatif. Media Persada.

Kurino, Y. D., Haryati, Y. D., Hasanah, U., Esa, Y. M., \& Kurino, Y. D. (2019). MODEL WORD SQUARE UNTUK MENINGKATKAN HASIL BELAJAR. Prosiding Seminar Nasional PGSD, 103, 308-312.

Kurniasih, I. (2016). Ragam Pengembangan Model Pembelajaran: Untuk Peningkatan Profesionalitas Guru. Kata Pena.

Lasmini, N. W. (n.d.). Meningkatkan Hasil Belajar Siswa Melalui Model Pembelajaran Kooperatif pada Mata Pelajaran IPA di Kelas V SD Negeri 2 Tatura. Jurnal Kreatif Tadulako Online, 4(4), 329-342.

Ngurah, A. A., Swapranata, A., Riastini, P. N., \& Japa, I. G. N. (2016). PENERAPAN MODEL PEMBELAJARAN WORD SQUARE UNTUK MENINGKATKAN HASIL BELAJAR IPA SISWA. 1.

Ni Pd. Mirah Kurniasari. dkk. (n.d.). Pengaruh Model Pembelajaran Word Square Berbantuan Media Gambar Terhadap Hasil Belajar IPS Siswa Kelas IV SD Gugus V Kecamatan Tegallalang. Ejournal Universitas Pendidikan Ganesha Singaraja.

Numayani. (2018). PENGGUNAAN MODEL PEMBELAJARAN WORD SQUARE UNTUK MENINGKATKAN HASIL BELAJAR SISWA PADA PELAJARAN PENDIDIKAN KEWARGANEGARAAN DI KELAS V SD NEGERI 054938 KAB. LANGKAT. SCHOOL EDUCATION JOURNAL, 8(1). 
Ratnasari, Y., Mardiati, Y., \& Fitriyah, C. Z. (2014). Penerapan Model Pembelajaran Word Square untuk Meningkatkan Aktivitas dan Hasil Belajar Siswa Kelas V Mata Pelajaran PKn Pokok Bahasan Keputusan Bersama di SDN Umbulrejo 01 Jember ( The Implementation of Word Square to Improve The Fifth Grade' s Learning. ARTIKEL ILMIAH MAHASISWA, 1(1), 1-5.

Reni Febriani, S. L. (2018). PENERAPAN MODEL PEMBELAJARAN WORD SQUARE UNTUK MENINGKATKAN HASIL BELAJAR SISWA KELAS X PADA MATA PELAJARAN AKUNTANSI PERUSAHAAN JASA. 1(1).

Sadirman. (2005). Interaksi dan Motivasi Belajar Mengajar. RajaGrafindo Persada.

Shadily, J. M. E. dan H. (1976). An English-Indonesia Dictionary (Kamus Inggris-Indonesia). PT. Gramedia Pustaka Utama.

Silmi Salsabila, Abas Asyafah, S. A. (2018). EFEKTIVITAS MODEL PEMBELAJARAN WORD SQUARE TERHADAP HASIL BELAJAR SISWA PADA MATA PELAJARAN PAI DAN BUDI PEKERTI KELAS IX DI SMP NEGERI 7 DEPOK Oleh : Silmi Salsabila, Abas Asyafah, dan Saepul Anwar. Jurnal Pendidikan Agama Islam -Ta'lim, 1(20), 53-61.

Suryani, K. (2018). PENGARUH MODEL PEMBELAJARAN WORD SQUARE TERHADAP AKTIVITAS DAN HASIL BELAJAR SISWA KELAS V MATA PELAJARAN BAHASA INGGRIS DI MIN 8 BANDAR LAMPUNG. UIN Raden Intan Lampung. 